\title{
Factors affecting the capital structure: New evidence from GCC countries
}

\author{
Audil Rashid Khaki \\ Department of Finance, American University of the Middle East, \\ Kuwait \\ Audil.Rashid@,aum.edu.k.w (Corresponding Author)
}

\author{
Ahmet Akin \\ Department of Finance, American University of the Middle East, \\ Kuwait \\ Abmet.Akin@,aum.edu.k.w
}

Abstract. This study aims to identify the firm-specific determinants of capital structure in the Gulf Cooperation Council (GCC) countries, namely Bahrain, Kuwait, Qatar, Oman, Saudi Arabia, and the United Arab Emirates. A number of regression models are employed on the data of 329 non-financial firms for the period between 2009 and 2017. The data has been analysed at both country level and regional level to look for the evidence on the major determinants of capital structure and the differences, if any. The findings indicate that size, tangibility, and growth opportunities have positive impact on leverage. On the other hand,

Received: October, 2019 1st Revision: December, 2019 Accepted: February, 2020 profitability, age, financial constraints, liquidity, and government ownership affect the leverage negatively. There is a weak evidence for a positive relationship between leverage and operating risk. The results also imply that the institutional features of GCC countries have a minor effect on the leverage within a general model for the region. Although GCC countries have a unique institutional environment that distinguishes them substantially from other countries, the current study provides evidence that the capital structure decisions are influenced by the same factors as in other developing countries.

Keywords: capital structure, leverage, firm-specific factors, GCC countries.

JEL Classification: G32 


\section{INTRODUCTION}

Circulation of capital is vital to broader economic growth which comes through sustainable and growing businesses. Businesses having profitable opportunities need more capital which is generally contributed by the owners (equity) of the business, however, firms oftentimes resort to borrowing funds from various sources to finance short-term as well as long-term projects. The cash flows thus generated, are reallocated away from the equity claimants, splitting cash streams by allocating relatively safer cash flows to debtholders and a riskier stream to stockholders. This mix of debt and equity financing in the firm's sources of funds is known as its capital structure.

Since the ground-breaking study by Modigliani and Miller (1958), great interest has been generated among researchers focusing on the relevance/irrelevance, and the determinants of capital structure (or leverage). The traditional view, that in perfect markets with no taxes, capital structure bears no relevance to the value of the firm, has aided the development of the current view that there exists an optimal mix of debt and equity for individual firms, which results from a tradeoff between costs and benefits of using debt in capital structure. The mainstream view is a result of the development of agency theory and the research related to the impact of bankruptcy costs on firm's value.

A large volume of empirical research is available on this topic, lending support to one or another theory of capital structure. Researchers around the globe are trying to identify the main determinants of capital structure, but oftentimes we find the empirical evidence contradicting each other, even about the basic facts. These contradictions and disagreements arise from the fact that most of these empirical studies are conducted to provide support to the desired point of view. And thus, evidently, it is easier to provide support to any theory by the subsequent studies. In spite of huge empirical literature available on the topic, while there is a consensus on the tendency of firms to have an optimal capital structure, there is no consensus on the major determinants affecting corporate financing behaviour.

Since literature on the determinants of capital structure in developing countries is scant, not much research is available on the determinants of capital structure across the GCC region, and thus, the current study is an attempt in this direction to determine the factors influencing corporate financing behaviour across the GCC region. The significance of the current study is that while institutional structure is being considered to be at the heart of capital structure research; and while GCC offers a contrast to the institutional structure of not only developed economies but also emerging ones, not much of research evidence has been collected to confirm the corporate financing behaviour in the region. This study analyses the firm-specific determinants of capital structure in the Gulf Cooperation Council (GCC) countries and contributes to literature in several ways. It brings in empirical evidence from a region with a unique institutional environment and a highly dominant banking sector. GCC countries are high-income countries with very low or no taxes on profits. The interest tax shields are considered as one of the important motivating factors for leverage. The current study, thus, aims to find out whether capital structure differs substantially when interest tax shields are trivial, as is the case with the GCC countries.

The current study also attempts to provide evidence in the context of bank-based economies of the GCC countries. Numerous studies comparing capital structure in bank-oriented and capital market-oriented economies are already available (Antonios, Guney \& Paudyal, 2008), the current study attempts to add more evidence. Besides, our choice of capital structure determinants allows us to examine the reliability of core firm-specific factors identified by Frank and Goyal (2009), but in the GCC context. Moreover, firm-specific factors in this study also include government ownership, which is widely observed in emerging economies in general and in GCC countries in particular. However, its influence on leverage is largely ignored and examined by a very few studies (Zou \& Xiao, 2006; Huang et al., 2001; Li et al., 2009; Pöyry \& Maury, 2010). 
Therefore, evidence for the impact of government ownership on capital structure is yet another contribution of this study to the existing literature on this subject.

The rest of the paper is organized as follows. Section 2 presents the review of literature, section 3 explains the institutional environment in the GCC countries and section 4 describes the data and the methodology. Finally, section 5 presents the empirical results, and section 6 discusses the results, conclusions are provided in the last section.

\section{LITERATURE REVIEW}

Much of the research on this topic, in the beginning, has largely been U.S. focused, determining the factors influencing corporate financing behaviour specifically in the U.S. firms. Researchers, lately, extended the results from U.S. to test the capital structure theories in developed countries having similar structure and characteristics to generate a consensus regarding the factors influencing corporate financing behavior. The first attempt in this direction was made by Rajan and Zingales(1995), who in their study in the G-7 region found that the same set of variables were relevant in the U.S. and the G-7, with regard to the determinants of corporate financing behaviour. Subsequent research, widely, has been US-focused or towards developed countries having institutional similarities with US (Rajan \& Zingales, 1995; Wald, 1999; Ozkan, 2001). Wald (1999), on the other hand, found that Institutional differences have a significant influence on corporate financing behaviour. He further demonstrates that the differences existing in different countries, therefore, would also create a disparity in the agency problem resulting in different capital structure choices.

While the major focus of researchers has been the developed countries exhibiting similar institutional structure and sharing similar characteristics, research about the determinants of capital structure in developing countries is scant. One of the prominent and earliest studies in the direction of testing capital structure theories in developing counties has been carried out by Booth et al. (2001). The study has been carried out to investigate whether the factors influencing the capital structure in developed countries could be generalized for developing countries. The results revealed that the corporate financing behaviour in developing countries was affected by the same set of factors as it was in developed countries, despite profound differences in the institutional structure. Furthermore, institutional differences were found to exhibit a significant influence on capital structure decisions. For instance, Skalická et al. (2017), reported that the legal structure of the organization and the taxation policies have a substantial effect on the equity component of firms' capital in Czech companies. Chen (2004) demonstrated through his study on Chinese firms that Chinese firms and firms in the developed countries differ mainly with respect to their choice of short-term and long-term financing. He further demonstrates that Chinese firms prefer short-term debt over long-term debt and thus, the explanatory power of capital structure theories in China might be undermined. Despite huge differences in the institutional structure, however, some factors were found to have significant explanatory power on the capital structure choice in China, similar to what is observed in developed countries.

Various theories have been suggested from time to time to explain corporate financing behaviour. One of the earliest theories in this direction is the trade-off theory, trade-off theory is still considered as a mainstream theory in the capital structure literature. This theory suggests that an optimal mix of debt and equity would lead to achieving maximum value for a firm; the debt-equity mix is in turn, determined by weighing the value of tax shield against various costs of financial distress, as well as agency costs and moral hazard(Myers, 1984). Merlo et.al. (2013) conclude that it is important for the businesses to use the right model to capture and evaluate their investment risk, as it is an important determinant for raising the capital at favorable terms, and thus having an optimal capital structure. Machek and Kubíček, (2018) also report 
significant support for the trade-off theory in Czech companies; they report that the agency problems are minimized with concentrated ownership structure, supporting organizational performance, however, only to a certain extent. They conclude that the firms must weigh the effectiveness of concentration of ownership structure against the marginal contribution to the organizational efficiency, and thus, there must be an optimal capital structure. In stark contrast to the static trade-off theories, an alternative theory known as the Pecking Order theory, is based on the premise that large firms strongly favor internal sources of funds to the external sources of fund, and debt to equity, if it resorts to external financing.

While the classic arguments in support of the trade-off theory are based on tax benefits and agency costs, recent empirical studies provide more support to the pecking order theory, which is based on asymmetric information issues and undervaluation and mispricing of intangible growth opportunities. Thus, the firms are expected to follow a particular order of preference, i,e., the retained earnings, debt, and equity respectively, when the need for financing is felt - (Myers, 1984; Myers \& Majluf, 1984). Although trade-off theories enjoy huge empirical support, and continue to be the mainstream of capital structure literature, it consistently fails to explain the observed corporate financing behaviour which can be better explained by pecking order theory. While both approaches have their own advantages, and failures, no theory qualifies to be a standalone theory in capital structure literature.

While sufficient empirical evidence exists in the literature in support of the trade-off theory, there is a good amount of evidence in favor of other capital structure theories too. For instance, Chen (2004) revealed that while trade-off theory fails to explain the corporate financing behaviour in Chinese firms, certain firmspecific factors affect the Chinese firms' leverage in the same way as in western countries. Strýčková (2017) found no evidence in support of the trade-off theory when it comes to the tax-based target capital structure, however, the study reports overwhelming support for the trade-of theory in regard to the bankruptcy costs. A similar phenomenon was observed by Booth et al. (2001), their study lends substantial support to the existence of asymmetry and thus support pecking order theory with no support for the trade-off theory. While the Trade-off theory still continues to be the mainstream in capital structure theories, its consistent failure to explain the observed corporate financing behaviour led to the emergence of an alternative approach based on information asymmetry (Myers \& Majluf, 1984), the pecking order hypothesis. This approach explains why large and profitable firms pile up their retained earnings (Tsyplakov, 2008) and why firms exhibit a tendency of preferring debt over equity in their financing decisions (Shyam-Sunder \& Myers, 1999).

The pecking order theory, however, is not acceptable in its classical form to explain the observed financing behaviour of the firms (Frank \& Goyal, 2009), as it encounters many other problems in explaining the firms' financing behaviour (Fama \& French, 2002; Frank \& Goyal, 2003). Strýčková (2017) reported that Czech companies follow a pecking order in their financing mix and exhibit both the differences and similarities with their European and American counterparts. Similar results were reported by Strýčková (2019), providing yet more support for the pecking-order theory in Czech companies, where insufficiency of the internal finances and the earnings volatility were found to be the most significant factor for designing a firms' debt policy. Chen (2004) demonstrated that due to the differences in the institutional structure like the ownership concentration, financial constraints and legal structure, the firms in China follow a new pecking-order theory, i.e., retained earnings, then equity, and debt only as a last resort.

Amidst the huge popularity of the existing capital structure theories, a yet another approach - signalling hypothesis, based on information asymmetry has evolved, where managers use capital structure to signal prospects to the poorly informed investors (Ross, 1977). This approach derives from market timing and is not backed by strong empirical evidence. Though the market timing theory correctly predicts some of the observed patterns in the capital structure, it largely fails to address the dominantly observed patterns as predicted by the trade-off theory, and thus, requires a considerable development to be considered a 
mainstream capital structure theory (Frank \& Goyal, 2009). More recent studies, however, lend more support to pecking order theory which prefers the use of internal financing over external financing (Chen \& Zhao, 2005; Kayhan \& Titman, 2007).

A long list of company-specific, Industry-specific and Macroeconomic factors like profitability, size, growth, industry practice, tangibility, age, financial constraints, tax shield, market conditions, inflation, riskiness, agency costs, ownership structure, orientation of financial markets, etc. are believed to shape and influence the capital structure of firms. The existing literature, however, has not been able to generate a consensus on the major determinants of capital structure because of the inherent differences across countries, industries, and firms. Frank and Goyal (2009), while evaluating the role of different factors on corporate financing behaviour exhibited by publicly traded American firms, found that a set of six core factors, viz. Industry Median Leverage, Tangibility, Profitability, Firm Size \& Maturity, Inflation or market conditions, and market to book assets ratio have a significant predictive power while the rest of the factors outlined in the existing literature only adds $2 \%$ predictive power to the model.

More studies in support or against the above-discussed capital structure theories are discussed in the corresponding sections in the empirical analysis and discussions section of the paper, later.

\section{DESCRIPTION OF INSTITUTIONAL ENVIRONMENT IN GCC COUNTRIES}

GCC Countries while having considerable similarities, differ in certain characteristics from both the developed and the developing economies. While GCC countries exhibit a considerable resemblance in terms of institutional structure, it is substantially different from both the advanced economies and emerging economies. GCC countries, in general, are largely dependent on hydrocarbons, heavy reliance on expats, expanding young national labor force, less developed capital markets, and a growing need for diversification. The countries in the GCC region are generally high-income countries with a small population as shown in Table 1 below. The countries are similar in terms of the business environment as indicated on the ease of doing business index except for UAE which ranks considerably higher than its peers (Table 1).

Table 1

Country Statistics

\begin{tabular}{|l|c|c|c|}
\hline \multicolumn{1}{|c|}{ Country } & GNI Per Capita (US\$)* & Population* & $\begin{array}{c}\text { Rank in the } \\
\text { Doing Business Index** }\end{array}$ \\
\hline Bahrain & 21,890 & $1,569,439$ & 43 \\
\hline Kuwait & 34290 & $4,137,309$ & 83 \\
\hline Oman & 15,140 & $4,829,483$ & 68 \\
\hline Qatar & 61,150 & $2,781,677$ & 77 \\
\hline Saudi Arabia & 21,600 & $33,699,947$ & 62 \\
\hline United Arab Emirates & 40,880 & $9,630,959$ & 16 \\
\hline
\end{tabular}

Sources:

*World Bank Database (2018). https://data.worldbank.org/. Accessed on 31/12/2019

**World Bank. (2020).Doing Business 2020. http://www.doingbusiness.org/. Accessed on 31/12/2019.

GCC countries have less developed capital markets, and a relatively strong but closed banking sector, with the size of bank assets far exceeding their capital market capitalization as indicated in Table 2 below. Besides, corporate bond issuance is very limited in the GCC countries. Research has largely ignored the orientation of financial markets in the determination of financing decisions. Whatever little research is available on this subject suggests considerable similarities and differences among the firms operating in 
capital market-oriented economies and bank-oriented economies (see among others, Fukuda \& Hirota, 1996; Ball et al., 2000; Antoniou et al., 2008).

Table 2

Financial System in GCC Countries (2015-2016)

\begin{tabular}{|l|c|c|c|}
\hline & $\begin{array}{c}\text { Deposit money banks' } \\
\text { assets to GDP }(\%)\end{array}$ & $\begin{array}{c}\text { Stock market capitalization to } \\
\text { GDP }(\%)\end{array}$ & $\begin{array}{c}\text { Corporate bond issuance } \\
\text { volume to GDP }(\%)\end{array}$ \\
\hline Bahrain & 103.03 & 61.13 & n/a \\
\hline Kuwait & 109.60 & $72.85^{\mathrm{a}}$ & 2.00 \\
\hline Oman & 87.99 & 48.43 & 0.31 \\
\hline Qatar & 147.65 & 98.13 & 0.65 \\
\hline Saudi Arabia & 69.03 & 68.37 & 0.09 \\
\hline United Arab Emirates & 116.13 & 59.38 & 1.69 \\
\hline
\end{tabular}

a Based on the authors' calculation. $\mathrm{n} / \mathrm{a}$ : Not available.

Deposit money banks' assets to GDP of Bahrain is from 2015. All other data is from 2016.

Source: The World Bank (2018). Global Financial Development Database (GFDD) 2017-2018.

Furthermore, GCC countries offer a unique opportunity to test the validity and application of different capital structure theories in a tax-free (corporate taxes on profits) environment with low bankruptcy costs, since the control of equity is dominated by the wealthy and influential private sector (Wafaa, 2010). Modigliani and Miller theory supports that in the presence of taxes, optimal capital structure exists under the homogenous expectations and perfect capital markets assumptions, and vice versa. The unique tax structure of GCC Countries, as presented in Table 3 below offers a case study for the relationship between taxes and corporate financing behaviour.

Table 3

Total Tax Rate, \% of Commercial Profit

\begin{tabular}{|l|c|c|c|c|}
\hline \multicolumn{1}{|c|}{ Country } & Total Tax Rate & Profit Taxes & Labor Taxes & Other Taxes \\
\hline Bahrain & 13.8 & 0.0 & 13.5 & 0.3 \\
\hline Kuwait & 13.0 & 0.0 & 13.0 & 0.0 \\
\hline Oman & 23.9 & 10.8 & 13.0 & 0.1 \\
\hline Qatar & 11.3 & 0.0 & 11.3 & 0.0 \\
\hline Saudi Arabia & 15.7 & 2.2 & 13.5 & 0.0 \\
\hline United Arab Emirates & 15.9 & 0.0 & 14.1 & 1.8 \\
\hline
\end{tabular}

Source: World Bank Group and PWC. (2017). Paying Taxes 2018.

http://www.doingbusiness.org/reports/thematic-reports/paying-taxes/. Accessed on 30/05/2018.

\section{DATA AND METHODOLOGY}

The sample of this study comprises of nonfinancial firms listed on the stock exchanges of GCC countries which consist of Bahrain, Kuwait, Oman, Qatar, Saudi Arabia, and the United Arab Emirates (UAE). All financial and utility companies are excluded from the study, as they have different financial structure than the other companies. Besides, only firms that have at least 3-year complete data for all the variables remain in the sample. Thus, we are left with unbalanced panel data of 2775 observations for 329 non-financial firms (17 Bahraini, 70 Kuwaiti, 71 Omani, 19 Qatari, 112 Saudi Arabian, and 40 Emirati) for the period of 2009-2017. All company-specific data has been obtained from Thomson Reuters Eikon in the US dollar and winsorized at $1 \%$ and $99 \%$ in order to eliminate the outliers. 
This study performs panel data analysis which has several advantages over cross-sectional or time series data analysis. Essentially, panel data analysis allows to control the individual heterogeneity, mitigates the multicollinearity problem, increases the degrees of freedom and data variability, and produces more accurate estimates. Panel data analysis has also limitations such as design and data collection problems in the panel surveys and cross section dependence in the macro panels. However, its advantages outweigh its limitations (Baltagi, 2013).

It is a common approach for multi- country studies to perform analysis on both pooled data of all countries and data of individual countries and/or country groups (Booth et al., 2001; Antoniou et al., 2008; Fan et al., 2012; Al-Najjar, 2013). For instance, Booth et al. (2001) examine the capital structure of 10 developing countries firstly through individual country models and then one pooled model of all countries. Their methodology enables to determine the impacts of firm specific factors and assess the significance of the country effect on the capital structure. This study follows the approach of Booth et al. (2001) to find out the drivers of capital structure in the GCC countries and conduct two-stage analysis. In the first stage of the analysis, leverage is regressed over selected company-specific variables, country by country, to examine the capital structure determinants on a country basis. Following regression model is applied for this purpose:

$$
L E V_{i, t}=\alpha+\beta X_{i, t}+\varepsilon_{i, t}
$$

where $L E V$ is the leverage, $X$ is a vector of firm-specific variables, and $\varepsilon$ is the error term.

In the second stage of the analysis, data on all GCC countries are combined and regression analyses are performed with pooled data of all countries in order to test the predictive power of one pooled model and detect the country effects on leverage. Firstly, the regression model above is re-estimated. Then, leverage is regressed over the country dummies as the only independent variables as specified below:

$$
L E V_{i, t}=\alpha+\eta D_{i, t}+\varepsilon_{i, t}
$$

where $D$ is a vector of country dummies and Bahrain is the base dummy. Lastly, a regression analysis is performed using both firm-specific variables and country dummy variables:

$$
L E V_{i, t}=\alpha+\beta X_{i, t}+\eta D_{i, t}+\varepsilon_{i, t}
$$

where dependent and independent variables are the same as defined above.

Definitions of variables are provided in Table 4. Book leverage (LEV) is the dependent variable in the regressions and it is the book value of total debt to book value of total assets ratio. Four of the regressors are the core firm-specific factors of leverage as defined by Frank \& Goyal (2009). Definitions of the core firm-specific factors are as follows: Size (SIZE) is the natural logarithm of total assets; growth opportunities (GROWTH) is the market-to-book value ratio which is measured as the market value of equity to book value of equity; tangibility (TANG) is the net plant, property and equipment to total assets ratio; profitability (PROFIT) is the ratio of operating profit to total assets. Other variables are liquidity, age, risk, dividend, and government ownership. Liquidity (LIQUID) is the cash and short-term investments to total assets ratio and age (AGE) is the number of years since the incorporation of the company. Business risk (RISK) is the absolute annual change in the profitability, government ownership (GOV) is the share of government in the ownership, and the dividend (DIV) is a dummy variable which equals one if the firm pays dividend in a given year, otherwise zero. 
Definitions of variables

\begin{tabular}{|l|l|}
\hline \multicolumn{1}{|c|}{ VARIABLE } & \\
\hline Dependent variable: & \\
\hline Leverage (LEV) & Ratio of book value of total debt to book value of total assets \\
\hline Independent variables: & \\
\hline Size (SIZE) & Natural logarithm of total assets \\
\hline Growth Opportunities (GROWTH) & Ratio of market value of equity to book value of equity \\
\hline Tangibility (TANG) & Ratio of net plant, property and equipment to total assets \\
\hline Profitability (PROFIT) & Ratio of operating profit to total assets \\
\hline Liquidity (LIQUID) & Ratio of cash and short-term investments to total assets \\
\hline Business Risk (RISK) & Absolute annual change in the profitability \\
\hline Dividend (DIV) & $\begin{array}{l}\text { A dummy variable which equals 1 if the firm pays dividend in a given year, } \\
\text { otherwise zero. }\end{array}$ \\
\hline Age (AGE) & Number of years since the incorporation of the company \\
\hline Government Ownership (GOV) & Share of government in the ownership \\
\hline
\end{tabular}

Table 5

Summary statistics

\begin{tabular}{|c|c|c|c|c|c|c|c|c|c|c|}
\hline & LEV & PROFIT & TANG & LIQUID & GROWTH & DIV & AGE & SIZE & GOV & RISK \\
\hline \multicolumn{11}{|l|}{ Babrain } \\
\hline Mean & 0.084 & 0.066 & 0.325 & 0.149 & 1.056 & 0.848 & 29.886 & 18.882 & 0.131 & 0.610 \\
\hline Std.Dev. & 0.109 & 0.069 & 0.266 & 0.126 & 0.537 & 0.360 & 14.241 & 1.377 & 0.191 & 1.286 \\
\hline Min & 0.000 & -0.155 & 0.020 & 0.005 & 0.332 & 0 & 3.882 & 16.359 & 0.000 & 0.003 \\
\hline Max & 0.586 & 0.291 & 0.977 & 0.482 & 2.416 & 1 & 54.291 & 22.029 & 0.732 & 8.070 \\
\hline \multicolumn{11}{|l|}{ Kuwait } \\
\hline Mean & 0.190 & 0.015 & 0.215 & 0.150 & 1.318 & 0.551 & 26.537 & 19.268 & 0.036 & 1.633 \\
\hline Std.Dev. & 0.176 & 0.096 & 0.203 & 0.166 & 1.495 & 0.500 & 16.766 & 1.343 & 0.114 & 3.642 \\
\hline Min & 0.000 & -0.391 & 0.000 & 0.001 & 0.270 & 0 & 5.138 & 15.910 & 0.000 & 0.004 \\
\hline Max & 0.617 & 0.254 & 0.853 & 0.830 & 11.885 & 1 & 112.003 & 23.068 & 0.685 & 23.07 \\
\hline \multicolumn{11}{|l|}{ Oman } \\
\hline Mean & 0.207 & 0.057 & 0.475 & 0.110 & 1.615 & 0.608 & 24.152 & 17.840 & 0.118 & 1.470 \\
\hline Std.Dev. & 0.195 & 0.082 & 0.255 & 0.123 & 1.311 & 0.490 & 13.833 & 1.426 & 0.193 & 4.810 \\
\hline Min & 0.000 & -0.279 & 0.002 & 0.000 & 0.126 & 0 & 7.017 & 14.268 & 0.000 & 0.004 \\
\hline Max & 0.887 & 0.275 & 0.981 & 0.599 & 7.984 & 1 & 112.003 & 21.400 & 0.753 & 36.62 \\
\hline \multicolumn{11}{|l|}{ Qatar } \\
\hline Mean & 0.215 & 0.073 & 0.358 & 0.136 & 1.940 & 0.830 & 22.247 & 20.677 & 0.174 & 0.439 \\
\hline Std.Dev. & 0.208 & 0.060 & 0.255 & 0.109 & 1.001 & 0.378 & 17.290 & 1.693 & 0.218 & 1.337 \\
\hline Min & 0.000 & -0.080 & 0.031 & 0.001 & 0.469 & 0 & 1.882 & 17.607 & 0.000 & 0.000 \\
\hline Max & 0.798 & 0.218 & 0.827 & 0.492 & 5.566 & 1 & 59.491 & 24.050 & 0.743 & 11.99 \\
\hline \multicolumn{11}{|c|}{ Saudi Arabia } \\
\hline Mean & 0.219 & 0.059 & 0.476 & 0.098 & 2.523 & 0.666 & 25.740 & 20.103 & 0.054 & 1.556 \\
\hline Std.Dev. & 0.191 & 0.088 & 0.233 & 0.097 & 1.894 & 0.472 & 14.428 & 1.525 & 0.116 & 5.136 \\
\hline Min & 0.000 & -0.202 & 0.000 & 0.003 & 0.756 & 0 & 2.045 & 16.062 & 0.000 & 0.004 \\
\hline Max & 0.668 & 0.350 & 0.889 & 0.506 & 12.242 & 1 & 115.003 & 24.109 & 0.596 & 37.64 \\
\hline \multicolumn{11}{|l|}{$U A E$} \\
\hline Mean & 0.170 & 0.039 & 0.356 & 0.121 & 1.315 & 0.696 & 25.796 & 20.034 & 0.118 & 1.211 \\
\hline Std.Dev. & 0.139 & 0.069 & 0.234 & 0.109 & 1.077 & 0.461 & 14.004 & 1.584 & 0.207 & 2.733 \\
\hline Min & 0.000 & -0.316 & 0.000 & 0.001 & 0.262 & 0 & 1.122 & 16.494 & 0.000 & 0.009 \\
\hline Max & 0.591 & 0.236 & 0.892 & 0.652 & 7.346 & 1 & 58.997 & 24.236 & 0.805 & 17.73 \\
\hline \multicolumn{11}{|l|}{ GCC } \\
\hline Mean & 0.197 & 0.048 & 0.390 & 0.119 & 1.808 & 0.651 & 25.555 & 19.397 & 0.083 & 1.397 \\
\hline Std. Dev. & 0.183 & 0.086 & 0.257 & 0.125 & 1.598 & 0.477 & 15.021 & 1.745 & 0.165 & 4.228 \\
\hline Min & 0.000 & -0.391 & 0.000 & 0.000 & 0.126 & 0.000 & 1.122 & 14.268 & 0.000 & 0.000 \\
\hline Max & 0.887 & 0.350 & 0.981 & 0.830 & 12.242 & 1.000 & 115.003 & 24.236 & 0.805 & 37.637 \\
\hline
\end{tabular}

Table 5 presents the summary statistics for the variables. The average leverage in the GCC countries is $19.7 \%$. Minimum leverage in the region is zero while the maximum leverage is $88.7 \%$. The leverage in Saudi 
Arabia, Qatar, and Oman is higher than the regional average, while the leverage in Bahrain and Kuwait is lower. The lowest leverage is in Bahrain with a ratio of $11.3 \%$.

Table 6

Correlation table

\begin{tabular}{|l|c|c|c|c|c|c|c|c|c|c|}
\hline & LEV & PROFIT & TANG & LIQUID & GROWTH & DIV & AGE & RISK & SIZE & GOV \\
\hline LEV & 1 & & & & & & & & & \\
\hline PROFIT & $-0.264^{* * *}$ & 1.000 & & & & & & & & \\
\hline TANG & $0.233^{* * *}$ & $0.034^{*}$ & 1.000 & & & & & & & \\
\hline LIQUID & $-0.357^{* * *}$ & $0.185^{* * *}$ & $-0.264^{* * *}$ & 1.000 & & & & & & \\
\hline GROWTH & -0.014 & $0.223^{* * *}$ & $0.140^{* * *}$ & 0.016 & 1.000 & & & & & \\
\hline DIV & $-0.160^{* * *}$ & $0.434^{* * *}$ & $-0.032^{*}$ & $0.075^{* * *}$ & $0.033^{* *}$ & 1.000 & & & & \\
\hline AGE & $-0.122^{* * *}$ & $0.077^{* * *}$ & $-0.032^{*}$ & $-0.046^{* *}$ & $-0.040^{* *}$ & $0.210^{* * *}$ & 1.000 & & & \\
\hline RISK & $-0.048^{* *}$ & $-0.201^{* * *}$ & -0.000 & $-0.047^{* *}$ & 0.007 & $-0.229^{* * *}$ & $-0.034^{*}$ & 1.000 & & \\
\hline SIZE & $0.309^{* * *}$ & $0.113^{* * *}$ & $0.061^{* * *}$ & $-0.111^{* * *}$ & -0.021 & $0.212^{* * *}$ & -0.006 & $-0.056^{* * *}$ & 1.000 & \\
\hline GOV & $-0.042^{* *}$ & $0.196^{* * *}$ & $0.108^{* * *}$ & $0.167^{* * *}$ & 0.011 & $0.151^{* * *}$ & $-0.097^{* * *}$ & $-0.033^{*}$ & $0.206^{* * *}$ & 1.000 \\
\hline
\end{tabular}

${ }^{*} \mathrm{p}<0.1,{ }^{* *} \mathrm{p}<0.05, * * * \mathrm{p}<0.01$

Correlations among the variables are depicted in Table 6 . The results indicate that there is a significant negative correlation between leverage and profitability, liquidity, dividend payment, age, risk, and government ownership. On the other hand, a significant positive correlation exists between leverage and tangibility and size. While the correlation is negative between leverage and growth, it is statistically insignificant. The correlations among the independent variables are not high, and thus, multicollinearity should not be a potential problem. In order to check for multicollinearity, variance inflation factor (VIF) is calculated for each regression. As shown in Table 7, the average VIF in each of the regression is less than 1.60 which indicates that multicollinearity is not a concern.

Table 7

Variance Inflation Factor

\begin{tabular}{|l|c|c|c|c|c|c|c|}
\hline & Bahrain & Kuwait & Oman & Qatar & Saudi Arabia & UAE & GCC \\
\hline PROFIT & 1.83 & 1.28 & 1.42 & 2.01 & 1.62 & 1.46 & 1.39 \\
\hline TANG & 1.42 & 1.18 & 1.21 & 1.27 & 1.10 & 1.11 & 1.13 \\
\hline LIQUID & 1.37 & 1.41 & 1.32 & 1.61 & 1.11 & 1.37 & 1.19 \\
\hline GROWTH & 1.96 & 1.13 & 1.05 & 1.54 & 1.25 & 1.08 & 1.08 \\
\hline DIV & 1.87 & 1.32 & 1.46 & 1.82 & 1.47 & 1.39 & 1.38 \\
\hline AGE & 1.78 & 1.22 & 1.04 & 1.57 & 1.14 & 1.39 & 1.07 \\
\hline RISK & 1.39 & 1.09 & 1.07 & 1.25 & 1.08 & 1.14 & 1.07 \\
\hline SIZE & 1.16 & 1.43 & 1.23 & 1.58 & 1.68 & 1.25 & 1.12 \\
\hline GOV & 1.61 & 1.24 & 1.12 & 1.95 & 1.61 & 1.19 & 1.15 \\
\hline Average & 1.60 & 1.26 & 1.21 & 1.62 & 1.34 & 1.26 & 1.18 \\
\hline
\end{tabular}

\section{EMPIRICAL RESULTS AND DISCUSSION}

\subsection{Results}

Fixed effect, random effect, and pooled regressions are the classical panel data regression models which can be used for the cross-country analysis. We employ the Lagrangian multiplier (LM) test and Hausman tests to select the appropriate model. Firstly, the LM test is applied to compare the random effect regression model and the pooled regression model. The null hypothesis of the LM test is rejected at $1 \%$ significance 
level for all countries, suggesting that pooled regression is not suitable for our analysis. Then Hausman test is conducted to select between fixed effect regression and random effect regression. If the null hypothesis is rejected, then fixed effect regression should be selected, otherwise, random effect regression would be suitable. The null hypothesis is rejected at 5\% significance level for all countries, except for Qatar. Therefore, Table 8 denotes the random effect regression results for Qatar and fixed effects regressions results for the other GCC countries as well as the chi-square statistics of LM and Hausman tests.

Table 8

Determinants of leverage

\begin{tabular}{|c|c|c|c|c|c|c|}
\hline & Bahrain & Kuwait & Oman & Qatar & Saudi Arabia & UAE \\
\hline \multirow[t]{2}{*}{ PROFIT } & -0.267 & $-0.292 * * *$ & $-0.388^{* * *}$ & $-1.064 * *$ & $-0.320^{* * *}$ & -0.119 \\
\hline & $(-1.24)$ & $(-5.51)$ & $(-3.95)$ & $(-2.18)$ & $(-4.25)$ & $(-1.09)$ \\
\hline \multirow{2}{*}{ TANG } & $0.315^{* * *}$ & $0.091^{* *}$ & 0.046 & $0.322^{* * *}$ & $0.176^{* * *}$ & 0.117 \\
\hline & $(3.03)$ & $(2.05)$ & $(0.49)$ & $(3.47)$ & $(3.16)$ & $(1.67)$ \\
\hline \multirow{2}{*}{ LIQUID } & 0.315 & $-0.191 * * *$ & $-0.169 *$ & $-0.217 *$ & $-0.121 * *$ & -0.074 \\
\hline & (1.5) & $(-3.25)$ & $(-1.97)$ & $(-1.94)$ & $(-2.05)$ & $(-1.30)$ \\
\hline \multirow[t]{2}{*}{ GROWTH } & 0.057 & 0.009 & $0.024^{* * *}$ & $0.053^{* * *}$ & $0.008^{* * *}$ & $0.036 * * *$ \\
\hline & $(1.42)$ & $(1.41)$ & $(4.32)$ & $(2.63)$ & $(3.85)$ & $(3.89)$ \\
\hline \multirow[t]{2}{*}{ DIV } & -0.040 & $-0.040^{* * *}$ & $-0.057 * * *$ & $-0.038^{* *}$ & $-0.023 * *$ & $-0.026 * *$ \\
\hline & $(-1.71)$ & $(-3.40)$ & $(-4.45)$ & $(-2.56)$ & $(-2.29)$ & $(-2.27)$ \\
\hline \multirow[t]{2}{*}{ AGE } & $-0.007 *$ & $-0.006^{* * *}$ & $-0.012^{* * *}$ & 0.002 & $-0.007 * * *$ & -0.001 \\
\hline & $(-1.79)$ & $(-3.10)$ & $(-3.93)$ & $(0.96)$ & $(-3.05)$ & $(-0.32)$ \\
\hline \multirow[t]{2}{*}{ RISK } & -0.004 & 0.000 & 0.001 & $-0.01 *$ & $0.001 * * *$ & 0.000 \\
\hline & $(-0.71)$ & $(0.41)$ & $(1.65)$ & $(-1.74)$ & $(2.77)$ & $(0.340)$ \\
\hline \multirow[t]{2}{*}{ SIZE } & $0.334 * * *$ & $0.129 * * *$ & $0.208^{* * *}$ & $0.068^{* *}$ & $0.185^{* * *}$ & $0.063^{* *}$ \\
\hline & $(3.85)$ & $(6.32)$ & $(7.54)$ & $(2.00)$ & $(8.28)$ & $(2.59)$ \\
\hline \multirow[t]{2}{*}{ GOV } & -0.014 & -0.081 & -0.104 & -0.067 & $-0.235^{*}$ & 0.006 \\
\hline & $(-0.16)$ & $(-0.84)$ & $(-1.50)$ & $(-0.44)$ & $(-1.71)$ & $(0.150)$ \\
\hline \multirow[t]{2}{*}{ _cons } & $-6.181 * * *$ & $-2.105^{* * *}$ & $-3.188^{* * *}$ & $-1.300^{* *}$ & $-3.386^{* * *}$ & $-1.140^{* *}$ \\
\hline & $(-3.61)$ & $(-5.42)$ & $(-6.76)$ & $(-2.01)$ & $(-7.96)$ & $(-2.35)$ \\
\hline $\mathrm{Chi}^{2}(1)-\mathrm{LM}$ test & 10.89 & 1266.11 & 950.06 & 211.34 & 1564.90 & 750.21 \\
\hline Chi $^{2}(9)-$ Hausman test & 97.02 & 46.20 & 141.94 & 11.19 & 27.53 & 17.12 \\
\hline R-sq & 0.593 & 0.407 & 0.470 & 0.574 & 0.415 & 0.267 \\
\hline F/Wald & 144.7 & 10.07 & 13.4 & 261.34 & 14.04 & 4.321 \\
\hline $\mathrm{N}$ & 132 & 594 & 607 & 169 & 921 & 352 \\
\hline
\end{tabular}

Regression results indicate that size is an important factor affecting the leverage in GCC countries. Its effect is positive and significant for all countries. Both tangibility and growth opportunities influence leverage positively in all countries, significantly in four out of six countries. Profitability, dividend payment, liquidity, and age have statistically significant negative effects on the leverage in at least four of six countries. A significant relationship between risk and leverage exists for Qatar and Saudi Arabia. Risk negatively affects leverage for Qatar whereas positively affects leverage for Saudi Arabia. Moreover, the results support the evidence for the negative effect of government ownership on the leverage with an exception of UAE. However, this effect is statistically significant only for Saudi Arabia.

We have carried out additional regression analyses to test the country effects on the leverage and examine the determinants of leverage via a common model for GCC countries. In this state of the analysis, we employ the random effect regression model as suggested by the LM test. Chi-square statistics are provided in Table 9 along with the regression results. 
Country Effects and a Common Model for GCC Countries

\begin{tabular}{|c|c|c|c|}
\hline & Model 1 & Model 2 & Model 3 \\
\hline \multirow[t]{2}{*}{ PROFIT } & $-0.338^{* * *}$ & & $-0.336 * * *$ \\
\hline & $(-7.88)$ & & $(-8.09)$ \\
\hline \multirow[t]{2}{*}{ TANG } & $0.158^{* * *}$ & & $0.150^{* * *}$ \\
\hline & $(4.82)$ & & $(4.63)$ \\
\hline \multirow[t]{2}{*}{ LIQUID } & $-0.168^{* * *}$ & & $-0.165^{* * *}$ \\
\hline & $(-4.93)$ & & $(-4.96)$ \\
\hline \multirow[t]{2}{*}{ GROWTH } & $0.012^{* * *}$ & & $0.013 * * *$ \\
\hline & (3.94) & & $(4.31)$ \\
\hline \multirow[t]{2}{*}{ DIV } & $-0.036 * * *$ & & $-0.036 * * *$ \\
\hline & $(-6.16)$ & & $(-6.21)$ \\
\hline \multirow{2}{*}{ AGE } & $-0.002^{* * *}$ & & $-0.002^{* * *}$ \\
\hline & $(-3.53)$ & & $(-3.74)$ \\
\hline \multirow[t]{2}{*}{ RISK } & 0.001 & & $0.001^{*}$ \\
\hline & $(1.63)$ & & $(1.66)$ \\
\hline \multirow[t]{2}{*}{ SIZE } & $0.076^{* * *}$ & & $0.091 * * *$ \\
\hline & $(11.18)$ & & $(12.42)$ \\
\hline \multirow[t]{2}{*}{ GOV } & $-0.106^{* * *}$ & & $-0.128^{* * *}$ \\
\hline & $(-3.21)$ & & $(-3.57)$ \\
\hline \multirow[t]{2}{*}{ Kuwait } & & $0.101 * * *$ & 0.032 \\
\hline & & $(3.75)$ & $(0.92)$ \\
\hline \multirow[t]{2}{*}{ Oman } & & $0.122^{* * *}$ & $0.157 * * *$ \\
\hline & & $(4.34)$ & $(4.20)$ \\
\hline \multirow[t]{2}{*}{ Qatar } & & $0.125^{* * *}$ & -0.067 \\
\hline & & $(2.67)$ & $(-1.38)$ \\
\hline \multirow[t]{2}{*}{ Saudi Arabia } & & $0.131 * * *$ & $-0.057^{*}$ \\
\hline & & $(5.1)$ & $(-1.70)$ \\
\hline \multirow[t]{2}{*}{ UAE } & & $0.083^{* * *}$ & -0.062 \\
\hline & & $(2.95)$ & $(-1.52)$ \\
\hline \multirow[t]{2}{*}{ _cons } & $-1.230 * * *$ & $0.089 * * *$ & $-1.537 * * *$ \\
\hline & $(-9.40)$ & $(4.51)$ & $(-10.88)$ \\
\hline $\mathrm{Chi}^{2}(1)-\mathrm{LM}$ test & $5,652.18$ & $6,122.04$ & $5,510.22$ \\
\hline R-sq & 0.235 & 0.027 & 0.285 \\
\hline $\mathrm{F}$ & 1161.44 & 30.72 & 312.82 \\
\hline $\mathrm{N}$ & 2775 & 2775 & 2775 \\
\hline
\end{tabular}

T-statistics based on standard errors corrected for heteroscedasticity and clustering at the firm level are in parentheses.

${ }^{*} \mathrm{p}<0.1, * * \mathrm{p}<0.05, * * * \mathrm{p}<0.01$

Fixed effect regression is not appropriate since there are time-invariant dummy variables for countries in the analysis. Firstly, a regression is estimated on the pooled data with only company-specific variables (Model 1). Results indicate that most variables are statistically significant except risk. Then regression analyses with only country dummy variables (Model 2) and with both the firm-specific and country dummy variables (Model 3) are performed. Dummy variable for Bahrain is excluded in the regressions. All country dummy variables have statistically significant positive coefficients in Model 2. Therefore, firms in Kuwait, Qatar, Oman, Saudi Arabia, and UAE have higher leverage than firms in Bahrain on average. However, the nationality of the firm explains only $2.7 \%$ of the variability in leverage. Besides, the inclusion of country dummy variables increases the R-square to $28.5 \%$ in Model 3 from $23.5 \%$ in Model 1 . Therefore, we can conclude that capital structure decisions in GCC countries are mainly driven by industrial and firm-specific 
factors rather than country factors. Tangibility, growth opportunities, and size have a significant and positive effect on leverage. On the other hand, profitability, liquidity, dividend payment, age, and government ownership have a significant negative relationship with leverage. However, the effect of risk is relatively weak and positive.

\subsection{Discussion and summary}

The results indicate that the corporate financing behavior in GCC follows a mix of the traditional trade-off approach and the pecking order theory. The results of this study and the alignment of our results with the theory are summarized in Table 10 and the detailed discussion on the results is presented below:

Profitability: Theoretically, profitable firms are least expected to go through financial distress, and thus interest \& tax shield adds value to such firms. Furthermore, agency costs are expected to enforce discipline on profitable firms and thus adds more value to them as these firms often face severe free cash flow problems (Jensen, 1986). However, in the GCC context, where there are no or very low taxes, the financial distress as well as tax-shield, seem to provide less incentive for higher leverage. Besides, GCC countries have bank-oriented financial markets in which access to financing, specifically with less developed capital markets, is considered to be difficult by corporate executives (Santos, 2015). Furthermore, the firms in GCC, due to the absence of taxes and rich ownership find it more attractive to reinvest the generated profits and thus, profits are considered as an important source of capital. The results imply a negative relationship between profitability and leverage consistent with the pecking order theory. More recent studies have demonstrated a negative relationship between leverage and profitability (Booth et al., 2001; Chen, 2004), and this negative relationship can neither be properly explained by transaction costs nor by taxes (Chen and Zhao, 2005). The negative relationship between profitability and leverage can be explained by increased information asymmetries which could lead to higher external financing premiums, under which firms prefer internal financing to external financing as predicted by the pecking order theory (Titman \& Wessels, 1988; Rajan \& Zingales, 1995; Cornelli et al., 1996; Bevan \& Danbolt, 2002). The negative relationship observed in the current study can also be explained by the inability of less developed capital markets to recognize and valuing growth opportunities (Booth et al., 2001). Chen (2004) demonstrates similar results and that in addition to supporting the pecking order hypothesis, Chinese firms prefer internal sources of finance over the external sources of finance due to a variety of other reasons like mispricing of projects, centrally planned economy, and government ownership of firms. The Chinese firms have been found to be financed mainly by equity, and the long term book debt comprises of only $7 \%$ (Chen, 2004), compared to an average of 51\% in developing countries (Booth et al., 2001). Bank Credit only meets the short term working capital requirements of the business while equity is mainly used to finance capital expenditures (Chen, 2004). The scope of tax effects predicted by the trade-off model is often limited in countries where corporates are mainly state-owned, bond markets are less developed, economies are centrally planned (Chen, 2004) as well as where economies operate on differential tax or no tax structure. 
Table 10

Results Summary

\begin{tabular}{|c|c|c|c|c|}
\hline $\begin{array}{c}\text { Variable } \\
\text { (Definition) }\end{array}$ & $\begin{array}{l}\text { Expected Sign } \\
\text { (Relationship) }\end{array}$ & Supporting Theory & $\begin{array}{c}\text { Results } \\
\text { (Relationship) }\end{array}$ & Theory Supported \\
\hline \multirow{2}{*}{ Size } & Negative & Pecking Order Theory & \multirow{2}{*}{ Positive } & \multirow{2}{*}{ Trade-off Theory } \\
\hline & Positive & Trade-off/ Signaling Theory & & \\
\hline \multirow{2}{*}{ Growth } & Negative & Trade-off Theory & \multirow{2}{*}{ Positive } & \multirow{2}{*}{ Pecking Order Theory } \\
\hline & Positive/Negative & Signaling/ Pecking Order Theory & & \\
\hline \multirow{2}{*}{ Tangibility } & Positive & Trade-off Theory & \multirow{2}{*}{ Positive } & \multirow{2}{*}{$\begin{array}{c}\text { Trade-off / Pecking } \\
\text { Order Theory }\end{array}$} \\
\hline & Positive & Pecking Order Theory & & \\
\hline \multirow{2}{*}{ Profitability } & Negative & Pecking Order Theory & \multirow{2}{*}{ Negative } & \multirow{2}{*}{ Pecking Order Theory } \\
\hline & Positive & Trade-off Theory & & \\
\hline \multirow{2}{*}{ Liquidity } & Positive & Trade-off Theory & \multirow{2}{*}{ Negative } & \multirow{2}{*}{ Pecking Order Theory } \\
\hline & Negative & Pecking Order Theory & & \\
\hline \multirow{2}{*}{ Age } & Positive & Pecking Order Theory & \multirow{2}{*}{ Negative } & \multirow{2}{*}{ Trade-off Theory } \\
\hline & Negative & Trade-Off Theory & & \\
\hline \multirow{2}{*}{$\begin{array}{l}\text { Financial } \\
\text { Constraint }\end{array}$} & Negative & Pecking Order Theory & \multirow{2}{*}{ Negative } & \multirow{2}{*}{ Pecking Order Theory } \\
\hline & Positive & Trade-Off Theory & & \\
\hline \multirow[b]{2}{*}{ Business Risk } & Negative & Trade-Off Theory & \multirow{2}{*}{$\begin{array}{c}\text { Negative/Positive } \\
\text { (Weak evidence) }\end{array}$} & \multirow{2}{*}{$\begin{array}{c}\text { Trade-off/Pecking } \\
\text { Order/Signaling } \\
\text { Theory }\end{array}$} \\
\hline & Negative & Pecking Order/Signaling Theory & & \\
\hline \multirow{2}{*}{$\begin{array}{l}\text { Government } \\
\text { Ownership }\end{array}$} & Positive & Trade-Off Theory & \multirow{2}{*}{ Negative } & \multirow{2}{*}{ Pecking Order Theory } \\
\hline & Negative & Pecking Order Theory & & \\
\hline
\end{tabular}

Size: Leverage seems to be positively related to the size of the firm in GCC countries that seem to be consistent with the theoretical predictions that large firms are more diversified, less prone to bankruptcy, face lesser asymmetric information problems, and thus easier to finance debt. This observation makes more sense in bank-oriented economies like GCC countries with less-developed capital and debt markets, as banks find it easy and convenient to lend to larger firms with substantial assets base. Large \& mature firms enjoying good reputation in the market, having a well-diversified portfolio, with a low default risk are likely to face lower agency costs and thus supposed to benefit from leverage as suggested by the trade-off theory (Warner, 1977; Titman \& Wessels, 1988; Rajan \& Zingales, 1995; Wald, 1999; Booth et al, 2001). Friend and Lang (1988) suggest that large firms often tend to have dilute ownership and managers, thusly, may be motivated to issue more debt; while in contrast Jensen (1986), Williamson (1988) and Stulz (1990) suggest that in order to control the behavior of managers, large firms tend to be highly levered as dilute ownership fails to control the management behavior. The pecking order theory, suggests a negative relationship between leverage and size (or age of the firms), as large and mature firms pile up their retained earnings until they are required to build additional capacity, and thus less motivated to approach external sources of funds (Tsyplakov,2008). Large and mature firms are expected to exhibit lower information asymmetry problems and thus should be able to issue equity - which is more information sensitive more easily, as compared to debt (Myers and Majluf, 1984; Kester, 1986; Petersen and Rajan, 1994). Smaller firms often find it difficult to resolve asymmetries with lenders' debt (Chung, 1993; Rajan \& Zingales, 1995; Grinbalt \& Titman, 1998) and carry higher costs of financial distress (Ozkan, 1996) and thus prefer equity over debt.

Growth Opportunities: Trade-off theory suggests that firms having larger growth (or growth opportunities), according to the trade-off theory tend to have lower debt in their capital structure, as growth opportunities are just intangible assets, and thus cannot be collateralized and also because growth opportunities can lead to sub-optimal investments(Myers, 1977; Jensen, 1986; Harris and Raviv, 1991). Leverage is negatively related to growth opportunities for the firms which fail to establish a recognition of their growth opportunities in capital markets (Lang et al., 1996). 
Contrary to the theoretical predictions of the trade-off theory, our results indicate a positive relationship between growth opportunities and leverage. The firms in GCC, thus seem to follow a pecking order in their financing structure as suggested by our results. Firms in GCC usually pile up their retained earnings to refinance new investments. However, if new projects require larger investments, the firms generally prefer to use debt over equity. The possible reasons for this financing behavior can be explained firstly by the tightly held rich ownership structure, which does not want to dilute ownership and control by issuing new stocks. Secondly, due to less developed capital markets, growth opportunities seem to be not recognized, and thus firms with growth opportunities seem to approach the predominant bank financing rather than issuing new equity. Lastly, cheap bank financing is often found attractive to finance new projects and investments.

Tangibility: The theoretical assumptions that tangibility is associated with the availability of collateral, reduces informational asymmetry, and thus firms having more tangible assets tend to have higher leverage. GCC firms having higher tangible assets seem to have higher leverage consistent with the predictions of both trade-off theory and pecking order theory. The results further reinforce the bank-oriented nature of financial markets in GCC, banks generally require tangible collaterals for loans, and thus tangibility occupies a central stage in financing behavior of firms in GCC, more so in less developed capital markets. Firms having more tangible and generic assets are expected to have more liquidation value (Viviani, 2008); moreover, tangible assets can be easily collateralized by placing a charge on them (Myers, 1977; Harris \& Raviv, 1991), reduce adverse selection and moral hazard problems (Long \& Malitz, 1992). Lenders often depend on the tangibility of assets, and since tangibility decreases the risk perception of banks, the firms having more tangible assets are expected to have higher leverage. The trade-off theory suggests a positive relationship between the tangibility of assets and leverage. Tangible assets are easier for outside lenders to evaluate and reduce the cost of financial distress, whereas firms making huge expenditures on $\mathrm{R} \& \mathrm{D}$, and thus, having unique products have a higher cost of financial distress (Long \& Malitz, 1985). Furthermore, according to the trade-off theory, firms having high liquidity ratios support higher debt due to their ability to meet short term debt obligations. In contrast, according to the pecking order theory, firms having excess liquidity can use excess funds to finance their investments (Ozkan, 2001). Furthermore, according to the Pecking order theory, tangibility reduces information asymmetry problems and thus makes issuance of equities much easier and less costly.

Age: The age and maturity of a firm is likely to strengthen the relationship with the suppliers of funds. Information asymmetries disappear with long term relationships and long histories, and thus the cost of external financing decreases. Older firms are well managed, better known, have better reputations, and thus face lower agency costs (Frank \& Goyal, 2009). This would facilitate firms to increase external financing and thus increase the leverage (Petersen and Rajan, 1994). On the contrary, as per the trade-off theory, older firms tend to accumulate retained earnings over time, while young firms are more dependent on external financing, and thus age and leverage are expected to have a positive relationship (Peterson \& Rajan, 1994; Michaelas et al, 1999; Viviani, 2008). Our results indicate a negative relationship between the age and leverage and are thus consistent with the expectations of the trade-off theory. This negative relationship observed in this study could also be due to weak financial markets, and the wealthy ownership of firms in the GCC region. The unique ownership and control structure of GCC firms, specifically large governmentowned firms, could distort the application of one or the other theory in the GCC context.

Financial Constraint: More recent studies are working under Myers (2003) assertion that "the theories are conditional, not general", and thus they argue that leverage is highly dependent on the organizational constraints and culture (Frank \& Goyal, 2009). Lemmon and Zender (2010) focus on the significance of financial constraints on leverage. The current study classifies firms as having a financial constraint if they are not paying dividends, while firms paying dividends are classified as financially unconstrained. Tsyplakov 
(2008) argues that firms tend to pile up their retained earnings before building additional capacity, and are thus constrained. The firms operating under the dividend constraint are thus expected to follow pecking order theory. From an agency perspective, on the contrary, firms facing a financial constraint are more likely to increase their target leverage ratio to curb managers' distorted behavior and enforcing more discipline (Jensen, 1986; Belkhir, et al, 2016). Our results are consistent with the pecking order theory, more of which could be attributed once again to the institutional climate and ownership structure of firms in the region.

Business Risk: Business risk is usually used as a proxy for the possibility of financial distress, and bankruptcy costs. Firms in GCC countries exhibit a low negative relationship between business risk and leverage, and our results of common model for GCC countries are consistent with the theoretical prediction that firms having higher volatility in their earnings tend to use lesser debt in their capital structure (Booth et al., 2001, Wald,1999; Titman and Wessels,1988). These findings can be explained by the fact that firms in GCC countries are owned by wealthy and influential investors, and thus tend to avoid debt as a source of funds (Sbeiti, 2010). These findings indicate that firms in GCC countries tend to follow the financing hierarchy of pecking-order theory when it comes to raising new funds.

Liquidity: While the trade-off theory predicts a positive relationship between liquidity and leverage, firms in GCC countries indicate that liquidity and leverage are negatively related. These findings are consistent with pecking order theory, the relationship, however, is weak and thus liquidity seems to have a very low but negative influence on leverage. The possible explanation for this observation is that the firms with higher liquidity would use their internal funds before debt. On the other hand, De Jong, Kabir, and Nguyen (2008) got mixed results for the effects of business risk; however, they found a weak relationship between liquidity and leverage.

Ownership Structure: A vast amount of literature is available on the impact of ownership structure on capital structure. Those studies have largely examined the ownership structure from the 'dilution of control' standpoint in terms of insider, foreign and institutional ownership (Jensen \& Meckling, 1976, Harris and Raviv, 1988; Friend and Lang, 1988; Berger et al., 1997; Chen et al., 2005; Chu, 2011). However, very few studies have examined the impact of government ownership on the capital structure (Zou \& Xiao, 2006; Huang et al., 2001; Li et al., 2009; Pöyry and Maury, 2010). They argue that firms with large state ownership tend to have higher debt in their capital structure primarily because firms with large government ownership mean lower chances of bankruptcy, and thus have better access to the debt market. They further argue that government-owned firms or firms with large government stake are averse to dilution of control. Our results indicate that there is a negative relationship between state-ownership and leverage in GCC firms. The contradicting results may be explained by the cash-rich nature of the governments in GCC, and the less developed debt markets in the region. The firms largely enjoy substantial government ownership (or otherwise, enjoy rich ownership), and thus there are no financial constraints. The firms in GCC would thus better exploit their retained earnings for financing before approaching the debt or capital markets. The firms don't seem to follow any theory strictly when it comes to capital structure.

\section{CONCLUSION}

Existing literature analyses the capital structure decisions of corporations in taxable environments. Large tax benefits such as interest tax shields are considered to be one of the important motivating factors for leverage. This study aims to bring in new evidence to the literature by analysing the capital structure of firms in the Gulf Cooperation Council (GCC) countries. GCC countries which are Kuwait, Saudi Arabia, United Arab Emirates, Oman, Qatar, and Bahrain, provide a low tax habitat for corporations and individuals. The analysis shows that the effects of most firm-specific characteristics on the capital structure of firms in GCC countries are consistent with the findings in the existing literature. Size, growth, and 
tangibility affect leverage positively. However, the impact of profitability, age, government ownership, and financial constraints is negative which can be attributed to the low tax environment, less developed capital markets, influential and wealthy ownership, and difficulty to access external financing. The relationship between leverage and operating risk is weak which is consistent with the findings for bank-based economies. Also, since the impact of country effects on the leverage is considerably low, the findings could be generalized for the GCC region.

\section{ACKNOWLEDGMENT}

The authors are thankful for the College of Business Administration Research Teams (COBART) initiative for creating a space for such academic collaborations. The present study is an outcome of COBART initiative at the AUM. The current study has received the required resources and research assistance built-in to support the COBART research collaborations.

\section{REFERENCES}

Al-Najjar, B. (2013). The financial determinants of corporate cash holdings: Evidence from some emerging markets. International business review, 22(1), 77-88.

Al-Saleh, N. (2009). Decisions on capital structure in a Zakat environment with prohibition of riba: The case of Saudi Arabia. The journal of risk finance, 10(5), 460-476.

Al-Sakran, S. A. (2001). Leverage determinants in the absence of corporate tax system: the case of non-financial publicly traded corporations in Saudi Arabia. Managerial Finance, 27(10/11), 58-86.

Antoniou, A., Guney, Y., \& Paudyal, K. (2008). The determinants of capital structure: capital market-oriented versus bank-oriented institutions. Journal of financial and quantitative analysis, 43(1), 59-92.

Ball, R., Kothari, S. P., \& Robin, A. (2000). The effect of international institutional factors on properties of accounting earnings. Journal of accounting and economics, 29(1), 1-51.

Baltagi, B. (2013). Econometric analysis of panel data. John Wiley \& Sons.

Barry, T. A., Lepetit, L., \&Tarazi, A. (2011). Ownership structure and risk in publicly held and privately owned banks. Journal of Banking \& Finance, 35(5), 1327-1340.

Bayless, M., \& Chaplinsky, S. (1991). Expectations of security type and the information content of debt and equity offers. Journal of Financial Intermediation, 1(3), 195-214.

Belkhir, M., Maghyereh, A., \& Awartani, B. (2016). Institutions and corporate capital structure in the MENA region. Emerging Markets Review, 26, 99-129.

Berger, P. G., Ofek, E., \& Yermack, D. L. (1997). Managerial entrenchment and capital structure decisions. The journal of finance, 52(4), 1411-1438.

Bevan, A. A., \& Danbolt, J. (2002). Capital structure and its determinants in the UK-a decompositional analysis. Applied Financial Economics, 12(3), 159-170.

Booth, L., Aivazian, V., Demirguc-Kunt, A., \&Maksimovic, V. (2001). Capital structures in developing countries. The journal of finance, 56(1), 87-130.

Chen, J. J. (2004). Determinants of capital structure of Chinese-listed companies. Journal of Business research, 57(12), 1341-1351.

Chen, L. and Zhao, Xinlei Shelly. (2005). Profitability, Mean Reversion of Leverage Ratios, and Capital Structure $\begin{array}{llll}\text { Choices } & \text { (February 2005). Available }\end{array}$ SSRN: https://ssrn.com/abstract=666992 or http://dx.doi.org/10.2139/ssrn.666992

Chen, Z., Cheung, Y. L., Stouraitis, A., \& Wong, A. W. (2005). Ownership concentration, firm performance, and dividend policy in Hong Kong. Pacific-Basin Finance Journal, 13(4), 431-449.

Chu, W. (2011). Family ownership and firm performance: Influence of family management, family control, and firm size. Asia Pacific Journal of Management, 28(4), 833-851.

Chung, K. H. (1993). Asset characteristics and corporate debt policy: an empirical test. Journal of Business Finance \& Accounting, 20(1), 83-98. 
Cornelli, F., R. Portes and M. Schaffer (1996) "The Capital Structure of Firms in Central and Eastern Europe," CEPR Discussion Paper No. 1392, London: Centre for Economic Policy Research.

DeAngelo, H., \&Masulis, R. W. (1980). Optimal capital structure under corporate and personal taxation. Journal of financial economics, 8(1), 3-29.

De Jong, A., Kabir, R., \& Nguyen, T. T. (2008). Capital structure around the world: The roles of firm-and countryspecific determinants. Journal of Banking \& Finance, 32(9), 1954-1969.

Danis, A., Rettl, D. A., \& Whited, T. M. (2014). Refinancing, profitability, and capital structure. Journal of Financial Economics, 114(3), 424-443.

Fama, E. F., \& French, K. R. (2002). Testing trade-off and pecking order predictions about dividends and debt. The review of financial studies, 15(1), 1-33.

Fan, J. P., Titman, S., \& Twite, G. (2012). An international comparison of capital structure and debt maturity choices. Journal of Financial and quantitative Analysis, 47(1), 23-56.

Frank, M. Z., \& Goyal, V. K. (2009). Capital structure decisions: which factors are reliably important? Financial management, 38(1), 1-37.

Friend, I., \& Lang, L. H. (1988). An empirical test of the impact of managerial self-interest on corporate capital structure. The Journal of Finance, 43(2), 271-281.

Fukuda, A., \& Hirota, S. I. (1996). Main bank relationships and capital structure in Japan. Journal of the Japanese and International Economies, 10(3), 250-261.

Harris, M., \& Raviv, A. (1988). Corporate control contests and capital structure. Journal of financial Economics, 20, 55-86.

Harris, M., \& Raviv, A. (1991). The theory of capital structure. The Journal of Finance, 46(1), 297-355.

Hovakimian, A., Opler, T., \& Titman, S. (2001). The Debt-Equity Choice. Journal of Financial and Quantitative Analysis, 36(1), 1-24. doi:10.2307/2676195

Huang, B. Y., Lin, C. M., \& Huang, C. M. (2011). The influences of ownership structure: Evidence from China. The Journal of Developing Areas, 209-227.

Jalilvand, A., \& Harris, R. S. (1984). Corporate behavior in adjusting to capital structure and dividend targets: An econometric study. The Journal of Finance, 39(1), 127-145.

Jensen, M. C., \& Meckling, W. H. (1976). Theory of the firm: Managerial behavior, agency costs and ownership structure. Journal of financial economics, 3(4), 305-360.

Jensen, M. C. (1986). Agency costs of free cash flow, corporate finance, and takeovers. The American economic review, 76(2), 323-329.

Kayhan, A., \& Titman, S. (2007). Firms' histories and their capital structures. Journal of financial Economics, 83(1), 1-32.

Kester, W. C. (1986). Capital and ownership structure: A comparison of United States and Japanese manufacturing corporations. Financial management, 5-16.

Khandelwal, P., Miyajima, M. K., \& Santos, M. A. O. (2016). The Impact of Oil Prices on the Banking System in the GCC. International Monetary Fund.

Lang, L., Ofek, E., \&Stulz, R. (1996). Leverage, investment, and firm growth. Journal of financial Economics, 40(1), 3-29.

Le, T. P. V., \& Tannous, K. (2016). Ownership structure and capital structure: A study of Vietnamese listed firms. Australian Economic Papers, 55(4), 319-344.

Lemmon, M. L., \& Zender, J. F. (2010). Debt capacity and tests of capital structure theories. Journal of Financial and Quantitative Analysis, 45(5), 1161-1187.

Li, K., Yue, H., \& Zhao, L. (2009). Ownership, institutions, and capital structure: Evidence from China. Journal of comparative economics, 37(3), 471-490.

Long, M. S., \&Malitz, I. B. (1985). Investment patterns and financial leverage. In Corporate capital structures in the United States (pp. 325-352). University of Chicago Press.

Long, M., \&Malitz, I. (1985). The investment-financing nexus: Some empirical evidence. Midland Corporate Finance Journal, 3(3), 53-59.

Lucas, D. J., \& McDonald, R. L. (1990). Equity issues and stock price dynamics. The journal of finance, 45(4), 1019-1043.

Machek, O., \& Kubíček, A. (2018). The relationship between ownership concentration and performance in Czech Republic. Journal of International Studies, 11(1), 177-186.

Marsh, P. (1982). The choice between equity and debt: An empirical study. The Journal of finance, 37(1), 121-144. 
Merlo, P., Dankiewicz, R., \& Ostrowska-Dankiewicz, A. (2013). Probabilistic and statistical methods of risk analysis in the investments effectiveness evaluation and their application in business practice. Actual problems of Economics, (12), 437-446.

Michaelas, N., Chittenden, F., \& Poutziouris, P. (1999). Financial policy and capital structure choice in UK SMEs: Empirical evidence from company panel data. Small business economics, 12(2), 113-130.

Modigliani, F., \& Miller, M. H. (1958). The cost of capital, corporation finance and the theory of investment. The American economic review, 48(3), 261-297.

Myers, S. C. (1977). Determinants of corporate borrowing. Journal of financial economics, 5(2), 147-175.

Myers, S. C. (1984). The capital structure puzzle. The journal of finance, 39(3), 574-592.

Myers, S. C., \&Majluf, N. S. (1984). Corporate financing and investment decisions when firms have information that investors do not have. Journal of financial economics, 13(2), 187-221.

Myers, S. C. (2003). Financing of corporations. In Handbook of the Economics of Finance (Vol. 1, pp. 215-253). Elsevier.

Omet, G., \& Mashharawe, F. (2002). The capital structure choice in tax contrasting environments: evidence from the Jordanian, Kuwaiti, Omani and Saudi corporate sectors. In The Economic Research Form 10* Annual Conference.

Ozkan, A. (2001). Determinants of capital structure and adjustment to long run target: evidence from UK company panel data. Journal of Business Finance \& Accounting, 28(1-2), 175-198.

Öztekin, Ö. (2015). Capital structure decisions around the world: which factors are reliably important?. Journal of Financial and Quantitative Analysis, 50(3), 301-323.

Petersen, M. A., \&Rajan, R. G. (1994). The benefits of lending relationships: Evidence from small business data. The journal of finance, 49(1), 3-37.

Pöyry, S., \& Maury, B. (2010). Influential ownership and capital structure. Managerial and Decision Economics, 31(5), 311 324.

Rajan, R. G., \&Zingales, L. (1995). What do we know about capital structure? Some evidence from international data. The journal of Finance, 50(5), 1421-1460.

Ritter, J. R., \&Warr, R. S. (2002). The decline of inflation and the bull market of 1982-1999. Journal of Financial and Quantitative Analysis, 37(1), 29-61.

Ross, S. (1977). The Determination of Financial Structure: The Incentive-Signalling Approach. The Bell Journal of Economics,8(1), 23-40. doi:10.2307/3003485

Santos, M. A. (2015). Integrated Ownership and Control in the GCC Corporate Sector (No. 15-184). International Monetary Fund.

Sbeiti, Wafaa. (2010). The determinants of Capital Structure: Evidence from the GCC Countries. International Research Journal of Finance and Economics, 47, 54-79.

Schwab, K. (2016). The global competitiveness report 2016-2017, ed. In WE Forum.

Shyam-Sunder, L., \& Myers, S. C. (1999). Testing static tradeoff against pecking order models of capital structure. Journal of financial economics, 51(2), 219-244.

Skalická Dušátková, M., Zinecker, M., \& Meluzín, T. (2017). Institutional Determinants of Private Equity Market in Czech Republic. Economics and Sociology, 10(4), 83-98.

Strýčková, L. (2017). The practice of capital structure choice in the Czech Republic: A comparative study based on the global data. Journal of International Studies, 10(2), 185-203.

Strýčková, L. (2019). Debt policy of companies in Czech Republic. Journal of International Studies, 12(3), 183-197.

Stulz, R. (1990). Managerial discretion and optimal financing policies. Journal of financial Economics, 26(1), 3-27.

Taggart Jr, R. A. (1985). Secular patterns in the financing of US corporations. In Corporate capital structures in the United States (pp. 13-80). University of Chicago Press.

Titman, S., \&Grinblatt, M. (1998). Financial market and corporate strategy. McCraw-Hill.

Titman, S., \& Wessels, R. (1988). The determinants of capital structure choice. The Journal of finance, 43(1), 1-19.

Tsyplakov, S. (2008). Investment frictions and leverage dynamics. Journal of Financial Economics, 89(3), 423-443.

Viviani, J. L. (2008). Capital structure determinants: an empirical study of French companies in the wine industry. International Journal of Wine Business Research, 20(2), 171-194.

Wald, J. K. (1999). How firm characteristics affect capital structure: an international comparison. Journal of Financial research, 22(2), 161-187. 
Warner, J. B. (1977). Bankruptcy, absolute priority, and the pricing of risky debt claims. Journal of Financial Economics, 4(3), 239-276.

Williamson, O. E. (1988). Corporate finance and corporate governance. The Journal of Finance, 43(3), 567-591.

World Bank. 2020. Doing Business 2020. Washington, DC: World Bank. DOI:10.1596/978-1-4648-1440-2. Retrieved December 31, 2019. http://www.doingbusiness.org/

World Bank Group and PWC. (2017). Paying Taxes 2018. Retrieved May 30, 2018

http://www.doingbusiness.org/reports/thematic-reports/paying-taxes/

World Bank (2018). Global Financial Development Database (GFDD) 2017-2018.

Zou, H., \& Xiao, J. Z. (2006). The financing behaviour of listed Chinese firms. The British Accounting Review, 38(3), 239-258. 